\section{Kearns-Sayre Syndrome with Reduced Plasma and Cerebrospinal Fluid Folate}

Richard J. Allen, MD, ${ }^{*}$ Salvatore DiMauro, MD, David L. Coulter, MD, $\$$ Alexander Papadimitriou, MD,$\S$ and Sheldon P. Rothenberg, MD\|

A young woman with Kearns-Sayre syndrome and progressive central nervous system deterioration over 15 years had decreased plasma and cerebrospinal fluid folate levels while receiving phenytoin for a seizure disorder. A muscle biopsy showed a "ragged red fiber" myopathy with reduced muscle carnitine and mitochondrial enzymes. Computed tomographic brain scans showed cerebral white matter hypodensities and bilateral calcification of the basal ganglia. The mechanism for the folate deficiency and altered ratio of plasma to cerebrospinal fluid folate is unknown, but the deficiency may be responsive to replacement therapy.

Allen RJ, DiMauro S, Coulter DL, Papadimitriou A, Rothenberg SP: Kearns-Sayre syndrome with reduced plasma and cerebrospinal fluid folate. Ann Neurol 13:679-682, 1983

Kearns-Sayre syndrome (KSS) is a multisystem disorder occurring in childhood. It is characterized by the triad of progressive external ophthalmoparesis, conduction heart block, and atypical pigmentary degeneration of the retina, and can be distinguished from other forms of "ophthalmoplegia plus" $[2,11,16]$. An accompanying encephalopathy originally observed postmortem may now be identified in computed tomographic (CT) brain scans as calcification of the basal ganglia or white matter hypodensities $[8,21,26]$. Muscle biopsies show ragged red fibers suggesting a mitochondrial disorder [3]. Endocrinopathies, particularly hypoparathyroidism, have also been observed in some patients with KSS [15]. The neurological symptoms of KSS resemble the syndrome of folate malabsorption [17]. We describe a patient with KSS who was found to have reduced plasma and cerebrospinal fluid (CSF) fo-

From the ${ }^{*}$ Department of Pediatrics and Neurology, University of Michigan, Ann Arbor, MI 48109, †Department of Neurology, Columbia University Medical Center, New York, NY 10032, $\neq$ Department of Neurology, University of Texas, Galveston, TX 77550 , \$Department of Neurology, Columbia University Medical Center, New York, NY 10032, and l'Brooklyn Veterans Administration State University, Downstate Medical Center, New York, NY 10029.

Received Sept 17, 1982, and in revised form Dec 15, 1982. Accepted for publication Dec 17, 1982.

Address reprint requests to Dr Allen. late levels without evidence of malabsorption. The patient improved after receiving oral folates, D, L-carnitine, and methionine [9].

\section{Case Report}

K.A. was born at 32 weeks' gestation and weighed $2.1 \mathrm{~kg}$. Following six weeks of incubator care, her growth and development were normal until age 9, when generalized absence and tonic-clonic seizures appeared and were treated with phenytoin and phenobarbital. Over the next 11 years, her schoolwork, memory, behavior, coordination, strength, and gait deteriorated. External ophthalmoparesis with bilateral pigmentary degeneration of the retina and bilateral ptosis was first observed at age 12 , as was proximal muscle weakness. A serum calcium of $5.0 \mathrm{mEq} / \mathrm{L}$ and an Ellsworth-Howard test suggested primary hypoparathyroidism. Thyroid and adrenal function tests were normal but a glucose tolerance test suggested mild chemical diabetes. Electroencephalograms were diffusely slow with frequent, generalized, high-voltage 2 to 3 cps spike-wave discharges. The CSF showed 27 mononuclear cells per milliliter and a protein of $194 \mathrm{mg} / \mathrm{dl}$. CSF glucose, cultures, and the colloidal gold curve were normal. Intravenous injection of edrophonium chloride (Tensilon) produced no effect. The patient was subsequently treated with phenytoin, phenobarbital, acetazolamide, vitamin $\mathrm{D}(10,000$ units), and an antacid (Amphojel).

At age 17, the patient's electrocardiogram showed left axis deviation of $-20^{\circ}$. IQ was 68 on the Wechsler Adult Intelligence Scale. The first muscle biopsy showed ragged red fibers, but serum creatine kinase levels were normal. Bilateral basal ganglion calcifications and white matter hypodensities were observed in CT brain scan. At age 21 the patient had an episode of unexplained coma. Physical examination was otherwise unchanged. All serum chemical analyses were normal except potassium $(2.2 \mathrm{mEq} / \mathrm{L})$, calcium $(13.2 \mathrm{mg} / \mathrm{dl})$, and amylase of 385 units, which had decreased to 120 units upon discharge from the hospital. The hematocrit was $24 \%$ and the bone marrow was hypocellular but without megaloblastic changes. Serum cobalamin (vitamin $\mathrm{B}_{12}$ ) and iron levels were normal. Serum calcium had decreased to $7.6 \mathrm{mg} / \mathrm{dl}$ at discharge. The patient recovered after several days of hydration and antibiotics. Phenobarbital was discontinued and phenytoin and vitamin $\mathrm{D}$ therapy maintained.

By 23 years of age the patient was bedridden and decreased plasma and CSF folate levels were found (Table 1) [23]. Phenytoin was discontinued. A second muscle biopsy showed a low free carnitine (Table 2); esterified carnitine fractions were also similarly decreased although the plasma carnitine was normal $(57$ and $38 \mathrm{nmol} / \mathrm{ml}$; mean of 59 controls \pm standard deviation, $51.07 \pm 11.09$; range, 35.069.8). The urine nitroprusside test (Brand Test) for sulfurcontaining amino acids was negative. Treatment was initiated with folic acid, D, L-carnitine, and methionine. A third, posttreatment needle biopsy indicated a slight increase in free carnitine from $2.7 \mathrm{nmol} / \mathrm{mg}$ noncollagen protein to 6.94 $\mathrm{nmol} / \mathrm{mg}$. During the following year the patient began to walk with the aid of a walker. When she was 25 years of age, a persistent cardiac conduction defect necessitated pacemaker implantation. 
Table 1. Plasma and CSF Folate Levels in Patient at Age 23 and in Control Subjects

\begin{tabular}{|c|c|c|c|}
\hline Sample & $\begin{array}{l}\text { Plasma Folate } \\
(\mathrm{ng} / \mathrm{ml})\end{array}$ & $\begin{array}{l}\text { CSF Folate } \\
(\mathrm{ng} / \mathrm{ml})\end{array}$ & $\begin{array}{l}\text { Plasma/CSF } \\
\text { Folate Ratio }\end{array}$ \\
\hline \multicolumn{4}{|l|}{ Patient } \\
\hline \multicolumn{4}{|c|}{ Pretreatment } \\
\hline $1 / 17 / 80$ & 1.9 & 1.1 & 1.7 \\
\hline $4 / 7 / 80$ & 1.0 & 1.0 & 1.0 \\
\hline \multicolumn{4}{|c|}{ Posttreatment } \\
\hline $9 / 25 / 80$ & 28.0 & 11.0 & 2.5 \\
\hline \multicolumn{4}{|l|}{ Control } \\
\hline Subjects ${ }^{\mathrm{a}}$ & $\begin{array}{c}4.5-12.9 \\
8.24 \pm 0.43^{b}\end{array}$ & $\begin{array}{c}\text { 3-4 times } \\
\text { plasma } \\
\text { folate } \\
\text { levels }\end{array}$ & $<1.0$ \\
\hline
\end{tabular}

${ }^{a}$ Values are expressed as range from 20 normal control subjects [23].

${ }^{b}$ Mean \pm standard error of the mean.

\section{Methods and Results}

Written informed consent was obtained for folate studies when the patient was age 23 . During hospitalization hemoglobin, hematocrit, mean corpuscular volume, and serum cobalamin levels were normal. Five, 10-methylenetetrahydrofolate reductase (5,10-MTHFR) activity was normal in leukocytes (study performed by Dr P. Wong, Rush Presbyterian-St. Lukes Hospital, Chicago [31]). A 24-hour urine formiminoglutamate excretion following oral administration of $100 \mathrm{mg} / \mathrm{kg}$ of histidine was normal $(10.8 \mathrm{mg})$ [14]. Plasma amino acids were normal with methionine ranging from 11.4 to $57.8 \mu \mathrm{mol} / \mathrm{L}$ (normal range, $6-39 \mu \mathrm{mol} / \mathrm{L}$ ) and a CSF methionine of $2.8 \mu \mathrm{mol} / \mathrm{L}$ (normal range, $2.6-3.0 \mu \mathrm{mol} / \mathrm{L}$ ) [25]. Folate tissue stores were saturated with $5 \mathrm{mg}$ per day of folic acid intramuscularly for three days before the oral folate absorption study. Then, following an oral dose of $40 \mu \mathrm{g}$ of folic acid per kilogram of body weight (a total of $1.45 \mathrm{mg}$, as folvite), folate levels increased to normal; from fasting the values at 30,60, 90, and 120 minutes were 37, 74, 70, 59, and $47 \mathrm{ng} / \mathrm{ml}$, respectively [6]. The fasting CSF folate was 17 $\mathrm{ng} / \mathrm{ml}$ with a persistently increased ratio of plasma to CSF folate of 2.2. Pretreatment plasma and CSF folate levels were low, and although plasma levels appeared to respond to oral folate treatment the ratio of plasma to CSF folate remained high (see Table 1). Replacement therapy included $15 \mathrm{mg}$ per day of folic acid, $500 \mathrm{mg}$ per day of methionine, and $10 \mathrm{~g}$ per day of D, L-carnitine. The carnitine was reduced to 2 gm per day when gastrointestinal intolerance appeared. Supplemental oral leucovorin ( $6 \mathrm{mg}$ per day) was given for the first two months in addition to folic acid.

\section{Discussion}

Abnormally low folate levels have been observed in senile dementias, convulsive disorders, neuropathies, and hypotonia in infants, conditions often without specific causes $[20,22,27]$. Classical homocystinuria (cystathionine synthase deficiency) may also be accompanied by reduced plasma folate [5]. Homocystinuria due to deficient 5,10-MTHFR has recently been associated with a reversed ratio of CSF to plasma folate and reduced muscle carnitine, as well as clinical evidence of a leukoencephalopathy and lipid storage myopathy $[1]$. Congenital folate malabsorption, a syndrome associated with ataxia, hypotonia, and mental retardation, is also accompanied by megaloblastosis, which was not found in this patient. Undernutrition and phenytoin therapy (which can also cause ophthalmoparesis) reportedly reduce plasma and CSF folates [18, 19, 29]. Severe neurological disability resulting primarily from low folates alone, however, is a disputed occurrence [20].

This patient had all the features of KSS, along with decreased muscle carnitine and mitochondrial enzymes. Studies excluded folate malabsorption and inborn errors of folate metabolism [12]. Although malnutrition and even phenytoin may have some effect on plasma folate, a defect in the distribution of folates is evident in this patient by the persistently low CSF folate levels. Folate deficiency has been associated with altered CSF amine metabolites and neuropsychiatric disorders, but the precise cause of the encephalopathy

Table 2. Mitochondrial Enzymes and Carnitine Concentration in Musde of Patient at Age 23 and in Control Subjects

\begin{tabular}{|c|c|c|c|}
\hline & Patient & $\begin{array}{l}\text { Control Subjects }{ }^{a} \\
(n=59)\end{array}$ & $\begin{array}{l}\text { Patient Compared to } \\
\text { Control Subjects }(\%)\end{array}$ \\
\hline Cytochrome $C$ oxidase ${ }^{b}$ & 0.27 & $2.38 \pm 0.44(22)$ & 11.3 \\
\hline Succinate cytochrome $C$ reductase ${ }^{b}$ & 0.054 & $1.16 \pm 0.47(17)$ & 4.65 \\
\hline Citrate synthetase $\mathrm{b}^{\mathrm{b}}$ & 1.25 & $7.88 \pm 2.52(12)$ & 15.9 \\
\hline Carnitine acetyltransferase $e^{b}$ & 1.45 & $1.57 \pm 0.48(21)$ & 92.3 \\
\hline Carnitine palmityltransferase $e^{r}$ & 0.60 & $7.45 \pm 1.44(58)$ & 8.05 \\
\hline Free carnitine ${ }^{d}$ & 2.70 & $19.33 \pm 4.77(68)$ & 13.9 \\
\hline
\end{tabular}

\footnotetext{
${ }^{2}$ Values are expressed as mean \pm standard deviation.

${ }^{b} \mu \mathrm{mol} / \mathrm{min} / \mathrm{gm}$ fresh tissue.

'nmol carnitine exchanged/min/gm fresh tissue.

${ }^{\mathrm{d}}$ nmol/mg noncollagen prorein.

Numbers in parentheses indicate number of control subjects.
} 
in KSS is unknown [4]. There was a prompt plasma folate response in this patient but the CSF folate was not significantly affected by treatment and the ratio of plasma to CSF folate did not approach normal [13]. Theoretical possibilities include an altered energydependent transport system or the excessive binding of folates by proteins in the choroid plexus. A specific primary defect was not apparent in this patient, however $[7,28,30]$. Three other patients in our clinic with calcification of the basal ganglia without the clinical triad of KSS had normal plasma and CSF folate levels (unpublished data, 1982).

The decreased activity of several mitochondria enzymes in the muscle biopsy of this patient is probably the nonspecific consequence of an unknown alteration of the mitochondria [24]. Low carnitine palmitoyltransferase activity has not previously been reported as a secondary phenomenon. One may speculate that there is a basic disorder of mitochondrial enzyme function of unknown cause in KSS which may be influenced by pharmacological amounts of pterins such as folic acid, as well as the related substrates methionine and carnitine [10]. Because a specific mechanism for the increased ratio of plasma to CSF folate in KSS is unknown, however, this abnormality may be an epiphenomenon with an associated nonspecific therapeutic response. Clinical improvement was evident, and there was an increase in muscle free carnitine, although this change may not be important. Additional studies are necessary in patients with KSS, to determine the frequency of abnormalities in the ratio of CSF to plasma folate and to identify a possible pathogenic mechanism.

Supported in part by Grant 5-MO-1RR42 from the Division of Research Resources of the National Institutes of Health and by a grant to the University of Michigan Section of Pediatric Neurology for the Pediatric Metabolic Disorder Clinic from the Deparment of Public Health and Human Services.

The authors thank Christine Willis, RN, and other nurses and dietitians at the University of Michigan Clinical Research Center for their help in carrying out these studies.

\section{References}

1. Allen RJ, Wong P, Rothenberg SP, DiMauro S, Headington J'T: Progressive neonatal leukoencephalomyopathy due to absent methylenetetrahydrofolate reductase, responsive to treatment (abstract). Ann Neurol 8:211, 1980

2. Berenberg RA, Pellock JM, DiMauro S, et al: Lumping or splitting? "Ophthalmoplegia-plus" or Kearns-Sayre syndrome? Ann Neurol 1:37-54, 1977

3. Bertorini T, Engel WK, DiChiro G, Dalakas M: Leukoencephalopathy in oculocraniosomatic neuromuscular disease with ragged-red fibers. Arch Neurol 35:643-647, 1978

4. Botez MI, Young SN, Bachevalier J, Gauthier S: Effect of folic acid and vitamin $\mathrm{B}_{12}$ deficiencies on 5 -hydroxyindoleaceric acid in human cerebrospinal fluid. Ann Neurol 12:479-484, 1982

5. Carey MC, Fennelly JJ, Fitzgerald O: Homocystinuria II. Sub- normal serum folate levels, increased folate clearance and effects of folic acid therapy. Am J Med 45:26-31, 1968

6. Chanarin I, Bennett MC: Absorption of folic acid and D-xylose as tests' of small intestine function. Br Med J 1:985-989, 1969

7. Colman NC, Herbert V: Folate-binding proteins. Ann Rev Med 31:433-439, 1980

8. Coulter D, Allen RJ: Abrupt neurological deterioration in children with Kearns-Sayre syndrome. Arch Neurol 38:247-250, 1981

9. Coulter D, Allen RJ, DiMauro S, Rothenberg S: Kearns-Sayre syndrome: a possible disorder of folate metabolism (abstract). Ann Neurol 8:222, 1980

10. DiMauro S, Trevisan C, Hays A: Disorders of lipid metabolism in muscle. Muscle Nerve 3:369-388, 1980

11. Drachman DA: Ophthalmoplegia plus. The neurodegenerative disorders associated with progressive external ophthalmoplegia. Arch Neurol 18:654-674, 1968

12. Erbe RO: Inborn errors of folate metabolism. N Engl J Med 293:753-757 (part 1) and 807-812 (part 2), 1975

13. Herbert V, Zalusky R: Selective concentration of folic acid activity in cerebrospinal fluid. Fed Proc 20:453, 1961

14. Hiatt HH, Goldstein M, Tagor H: Urinary excretion of formiminoglutamic acid by human subjects after antifolic acid therapy. J Clin Invest 37:329-332, 1959

15. Horwitz SJ, Roessmann U: Kearns-Sayre syndrome with hypoparathyroidism. Ann Neurol 3:513-518, 1978

16. Kearns TP, Sayre GP: Retinitis pigmentosa, external ophthalmoplegia, and complete heart block. Unusual syndrome with histologic study in one of two cases. Arch Ophthal 60:280-289, 1958

17. Lanzkowsky P, Erlanosson ME, Bezan AI: Isolated defect of folic acid absorption associated with mental retardation and cerebral calcification. Blood 34:452-465, 1969

18. Marcus JC, Pettifor JM: Folate and mineral malabsorption in poorly nourished epileptic children. Arch Neurol 37:772, 1980

19. Mattson RH, Gallagher BB, Reynolds EH: Folate therapy in epilepsy. Arch Neurol 29:78-81, 1973

20. Melamed E: Neurological disorders related to folate deficiency. In Botez MI, Reynoids EH (eds): Folic Acid in Neurology, Psychiatry, and Internal Medicine. New York, Raven, 1979, pp $423-426$

21. Okamoto T, Mizuno K, lida M, Sobve I, Muicoyama M: Ophthalmoplegia plus: its occurrence with periventricular diffuse low density on computed tomography scan. Arch Neurol $38: 423-426,1981$

22. Reynolds EH: Cerebrospinal fluid folace: clinical studies. In Botez MI, Reynolds EH (eds): Folic Acid in Neurology, Psychiatry, and Internal Medicine. New York, Raven Press, 1979, pp $195-203$

23. Rothenberg $S$, DaCosta $D$, Rosenberg $Z$ : A radio assay for serum folate: use of a two-phase sequential-incubation, ligandbinding system. $\mathrm{N}$ Engl J Med 286:1135, 1972

24. Scholte HR, Busch HFM, Luyt-Houwen IEM: Functional disorders of mitochondria in muscular diseases-respiratory chain phosphorylation-the carnitine system. In Busch HFM, Jennekens FGI, Scholte HR, Mefar b.v., (eds): Mitochondria and Muscular Diseases. Beetsterzwaag, The Netherlands, Mefar, b.v. 1981 , pp 133-143

25. Scriver CR, Rosenberg LE: Distribution of amino acids in body fluids. In Scriver CR, Rosenberg LE (eds): Amino Acid Metabolism and Its Disorders, Vol X, Major Problems in Clinical Pediatrics. Philadelphia, W.B. Saunders, 1973, pp 39-60

26. Seigel RS, Seeger JF, Gabrielsen TO, Allen RJ: Compured tomography in oculocraniosomatic disease (Kearns-Sayre syndrome). Radiology 130:159-164, 1979

27. Shapira Y, Zvi AB, Statter M: Folic acid deficiency: a reversible cause of infantile hypotonia. J Pediatr 93:984-986, 1978 
28. Spector R: Cerebrospinal fluid folate and the blood brain barrier. In Botez Ml, Reynolds EH (eds): Folic Acid in Neurology, Psychiatry, and Internal Medicine. New York, Raven, 1979, pp $187-193$

29. Spector RH, Davidoff RA, Schwartzman RJ: Phenytoin-induced ophthalmoplegia. Neurology 26:11031-11034, 1976

30. Spector R: Identification of a folate binding macromolecule in rabbit choroid plexus. J Biol Chem 252:3364-3370, 1977

31. Wong PWK, Justice P, Berlow S: Detection of homozygotes and heterozygotes with methylenetetrahydrofolate reductase deficiency. J Lab Clin Med 90:283-288, 1977

\section{Evidence that Lack of Deoxyribonucleic Acid Repair Causes Death of Neurons in Xeroderma Pigmentosum}

Jay H. Robbins, MD, * Ronald J. Polinsky, MD, $\uparrow$ and Alan N. Moshell, MD*t

Xeroderma pigmentosum (XP) is an autosomal recessive disorder with hypersensitivity to the lethal effects of ultraviolet radiation caused by inherited defects in deoxyribonucleic acid (DNA) repair processes. Some patients with XP develop a primary neuronal degeneration which has been thought to result from unrepaired damage in neuronal DNA. Five years ago we reported that cultured skin fibroblasts from a 12-yearold girl with XP, who then had only one major neurological abnormality of the disease, had a sensitivity to ultraviolet radiation intermediate between that of XP patients with numerous neurological abnormalities and those with none. Recent neurological studies reveal that she has a slowly but progressively developing sensorineural deafness as well as cerebellar and motor dysfunction typical of XP. The results support the postulate that defective DNA repair is associated with premature neuron death.

Robbins JH, Polinsky RJ, Moshell AN: Evidence that lack of deoxyribonucleic acid repair causes death of neurons in xeroderma pigmentosum. Ann Neurol 13:682-684, 1983

Xeroderma pigmentosum (XP) is an autosomal recessive disease characterized by accelerated actinic damage

From the *Dermatology Branch, National Cancer Institute, the $\dagger$ Laboratory of Clinical Science, National Institute of Mental Health, and the $\dagger$ Arthritis, Musculoskeletal and Skin Diseases Program, National Institute of Arthritis, Diabetes, and Digestive and Kidney Diseases, National Institutes of Health, Bethesda, MD 20205.

Received Oct 8, 1982. Accepted for publication Nov 20, 1982.

Address reprint requests to Dr Robbins, Clinical Center, Room 12N258, National Institutes of Health, Bethesda, MD 20205.

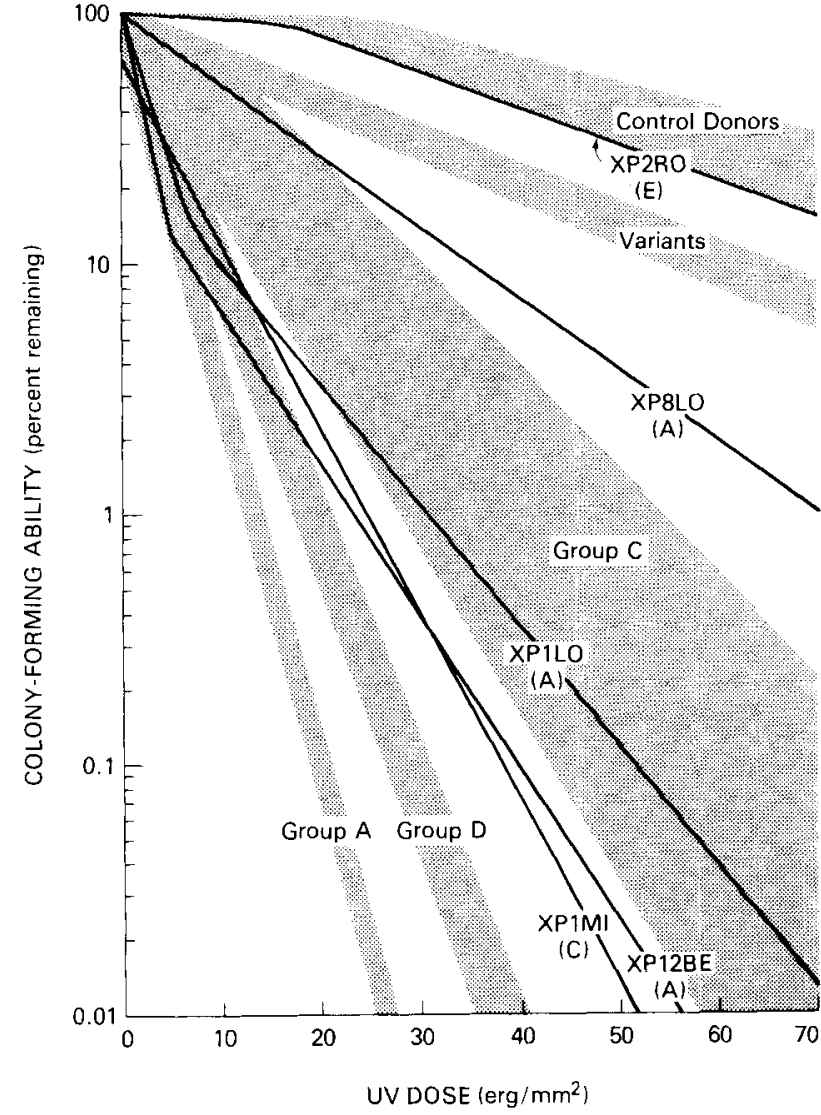

Fig 1. Relationsbip between neurological abnormalities of patients with $X P$ and the post- $U V$ colony-forming ability of their fibroblasts. Explanation and discussion are in text. This figure is based substantially on Figure 2 of ref 13 but with the normal donor zone modified in accord with ref 3 .

to skin and other sun-exposed tissues [15]. Some patients with XP also have a primary neuronal degeneration [15]. The major neurological features of $\mathrm{XP}$ include microcephaly, progressive mental deterioration, choreoathetosis, ataxia, sensorineural deafness, areflexia, extensor plantar responses, spasticity, and a neuropathic electromyograph and muscle biopsy [15]. Loss of neurons is prominent in the pyramidal cells of the cortex, the Purkinje cells of the cerebellum, the deep nuclei of the basal ganglia and cerebellum, the zona compacta of the substantia nigra, and the locus ceruleus $[15,17]$. In advanced cases the spinal cord pathology resembles that observed in cases of Friedreich ataxia [17]. The constellation of most of these findings with retarded growth and sexual development has been referred to as the De Sanctis-Cacchione syndrome $[5,15]$.

Cells from patients with XP show abnormal repair of DNA when damaged by ultraviolet (UV) radiation or certain UV-mimetic chemicals $[6,15]$. There are currently eight known genetic forms of XP: the variant form, which has abnormal postreplication repair but a normal rate of UV-induced unscheduled DNA repair 